\title{
Radiation Therapy (RT) Target Volume Definition for Peripheral Primitive Neuroectodermal Tumor (PPNET) by Use of Multimodality Imaging: An Original Article
}

\author{
Selcuk Demiral*, Omer Sager, Ferrat Dincoglan and Murat Beyzadeoglu \\ Department of Radiation Oncology, Gulhane Medical Faculty, Ankara, Turkey
}

*Corresponding author: Selcuk Demiral, Gulhane Medical Faculty, Department of Radiation Oncology, Gn.Tevfik Saglam Cad. 06018, Etlik, Kecioren, Ankara/Turkey

\section{ARTICLE INFO}

Received: 慧 March 12, 2021

Published: March 22, 2021

Citation: Selcuk D, Omer S, Ferrat D, Murat B . Radiation Therapy (RT) Target Volume Definition for Peripheral Primitive Neuroectodermal Tumor (PPNET) by Use of Multimodality Imaging: An Original Article. Biomed J Sci \& Tech Res 34(4)-2021. BJSTR. MS.ID.005586.

Abbreviations: PNET: Primitive Neuroectodermal Tumor; RT: Radiation Therapy; MRI: Magnetic Resonance Imaging; CT: Computed Tomography; PPNET: Peripheral Primitive Neuroectodermal Tumor; IMRT: Intensity Modulated Radiation Therapy; IGRT: Image Guided Radiation Therapy; BART: Breathing Adapted Radiation Therapy; ART: Adaptive Radiation Therapy; LINAC: Linear Accelerator

\section{ABSTRACT}

Objective: Primitive neuroectodermal tumor (PNET) refers to a group of highly malignant tumors consisting of small round cells of neuroectodermal origin which may be subdivided into central or peripheral PNET (PPNET) types. Radiation therapy (RT) has been used as part of multimodality management to improve treatment results, however, radiation induced toxicities remain to be critical concerns particularly for pediatric patients with PPNET. In this original research article, we evaluated RT target volume definition for PPNET by use of multimodality imaging.

Materials and Methods: RT target volume definition for PPNET with multimodality imaging by incorporation of magnetic resonance imaging (MRI) or by computed tomography (CT)-simulation images only has been assessed for patients receiving RT for PPNET.

Results: Ground truth target volume serving as the reference for actual treatment and for comparison purposes has been meticulously defined by the board certified radiation oncologists following comprehensive evaluation, colleague peer review, collaboration, and consensus. A group of experts from radiology, surgery, medical and radiation oncology departments have decided for individualized patient management after thorough multidisciplinary assessment. Synergy (Elekta, UK) LINAC has been utilized for irradiation. RT target volume definition with CT only and with incorporation of CT-MR fusion has been assessed comparatively. As the primary result of this study, ground truth target volume has been found to be identical with target volume determination with CTMR fusion based imaging.

Conclusion: Multimodality imaging with incorporation of MRI in the target definition process may be considered for improving the accuracy and precision despite the need for further supporting evidence.

Keywords: Peripheral Primitive Neuroectodermal Tumor (PPNET); Radiation Therapy (RT); Magnetic Resonance Imaging (MRI)

\section{Introduction}

Primitive neuroectodermal tumor (PNET) refers to a group of highly malignant tumors consisting of small round cells of neuroectodermal origin which may affect both soft tissues and bones and these rare but aggressive variant of small round cell carcinomas typically arising from the neural crest cells may be subdivided into central or peripheral PNET (PPNET) types [1-5]. Patients with PPNET may suffer from several symptoms depending on lesion size, localization and association with critical structures. No standardized guideline exists for management of PPNET partly due to the rarity of cases arising in different body sites, however, 
multimodal treatment may be utilized as in Ewing sarcoma family of tumors [1-5]. Within this context, surgery, systemic treatments and radiation therapy (RT) may be included in combined modality management of PPNET to achieve improved therapeutic outcomes [1-5]. Despite intensive management, these tumors may typically follow an aggressive disease course with distant metastases in a considerable proportion of patients.

RT has been used as part of multimodality management to improve treatment results, however, radiation induced toxicities remain to be critical concerns particularly for pediatric patients with PPNET. To this end, there has been extensive effort to improve the toxicity profile of radiation delivery to achieve better functionality and quality of life. Precise, accurate, and focused treatment techniques have been developed to improve sparing of critical structures and surrounding normal tissues while effectively irradiating the target volumes. In the context of radiation oncology discipline, there have been substantial progress in recent years with tremendous advances by introduction of adaptive irradiation strategies and modernized treatment delivery techniques with incorporation of Intensity Modulated Radiation Therapy (IMRT), Image Guided Radiation Therapy (IGRT), Breathing Adapted Radiation Therapy (BART), Adaptive Radiation Therapy (ART), automatic segmentation methods, molecular imaging techniques and stereotactic irradiation strategies [6-41]. In this original research article, we evaluated RT target volume definition for PPNET by use of multimodality imaging.

\section{Materials and Methods}

RT target volume definition for PPNET with multimodality imaging by incorporation of magnetic resonance imaging (MRI) or by computed tomography (CT)-simulation images only has been assessed for patients receiving RT for PPNET. Ground truth target volumes which served as reference for actual treatment and for comparison purposes have been determined by the board certified radiation oncologists following comprehensive evaluation, colleague peer review, collaboration, and consensus. Comprehensive patient evaluation has been performed with consideration of lesion size and localization, symptomatology, logistical issues, and expected outcomes of treatment. A group of experts including radiologists, surgeons, medical and radiation oncologists have decided for individualized patient management after thorough multidisciplinary assessment. RT simulation has been performed at CT-simulator (GE Lightspeed RT, GE Healthcare, Chalfont St. Giles, UK) available at our tertiary cancer center. Planning CT images have been acquired and then transferred to the delineation workstation (SimMD, GE, UK) for contouring of treatment volumes and nearby critical structures. Either CT-simulation images only or fused CT and MR images have been used for the purpose of RT target volume definition. Treatment planning objectives included adequate target coverage with minimal exposure of surrounding normal tissues.
Target volumes determined by CT only and with incorporation of CT-MR fusion have been assessed comparatively. Treatment delivery has been accomplished by use of Synergy (Elekta, UK) linear accelerator (LINAC) with routine incorporation of IGRT by electronic portal imaging and kilovoltage cone beam CT.

\section{Results}

Treatment planning has been acomplished by using the available treatment planning systems at our department with the primary objectives of adequate target coverage with minimal exposure of normal tissues for improving the therapeutic ratio. Ground truth target volume serving as the reference for actual treatment and for comparison purposes has been meticulously defined by the board certified radiation oncologists following comprehensive evaluation, colleague peer review, collaboration, and consensus. A group of experts from radiology, surgery, medical and radiation oncology departments have decided for individualized patient management after thorough multidisciplinary assessment. Synergy (Elekta, UK) LINAC has been utilized for irradiation. RT target volume definition with CT only and with incorporation of CT-MR fusion has been assessed comparatively. As the primary result of this study, ground truth target volume has been found to be identical with target volume determination with CT-MR fusion based imaging.

\section{Discussion}

Although PPNET is relatively rare, it may cause severe symptoms warranting prompt management. Symptoms may vary depending on lesion size, localization and association with critical structures. Multidisciplinary management of PPNET has typically been derived from Ewing family of tumors. Surgery, systemic treatment, and RT has been included in multidisciplinary management. However, an aggressive disease course may be observed in a considerable proportion of patients with PPNET despite intensive therapies. RT has been utilized as part of multidisciplinary treatment approaches, however, adverse effects of irradiation constitute major concerns particularly for pediatric patients with PPNET. Besides achieving disease control, pertinent aspects of contemporary patient management include preservation of functionality with improved toxicity profile of delivered therapies.

Adverse effects of irradiation may be severe in some patients leading to deterioration in quality of life and functionality. In this context, every effort should be spent to improve the toxicity profile of radiation delivery. Contemporary radiotherapeutic approaches allow for progress in management with irradiation, however, there is room for further achievements to improve the therapeutic ratio. Target definition composes a critical aspect of radiotherapeutic management of PPNET. While RT planning has been typically based on CT simulation of the patients in treatment position, incorporation of data from multimodality imaging may add to the accuracy and precision of target definition process. Generation of 
larger than actual treatment volumes should not be considered as a feasible solution to geographic misses since this may significantly increase exposure of normal tissues in close vicinity of the tumor which may lead to excessive toxicity.

On the other hand, generation of smaller than actual volumes should also be discouraged since it may result in inadequate target coverage with subsequent treatment failures. From this prospect, accuracy and precision in target definition are indispensable components of successful PPNET management. Combined use of CT and MR images may significantly improve target definition for accurate and precise irradiation of PPNET. Several other studies have also addressed incorporation of multimodality imaging for RT target determination [42-68]. Admittedly, determination of the ground truth target volume may be prone to variations due to possible interobserver variations. In this study, board certified radiation oncologists have performed the definition of ground truth target volumes following detailed evaluation, colleague peer review, collaboration, and consensus to achieve optimal results. Our study may add to the growing body of literature by supporting the utility of multimodality imaging for accurate and precise target volume definition for PPNET.

\section{Conclusion}

In conclusion, multimodality imaging with incorporation of MRI in the target definition process may be considered for improving the accuracy and precision despite the need for further supporting evidence.

\section{References}

1. Dehner LP (1986) Peripheral and central primitive neuroectodermal tumors. A nosologic concept seeking a consensus. Arch Pathol Lab Med 110: 997-1005.

2. Zimmermann T, Blütters-Sawatzki R, Flechsenhar K, Padberg WM (2001) Peripheral primitive neuroectodermal tumor: challenge for multimodal treatment. World J Surg 25(11): 1367-1372.

3. Kumar AA, Barodawala S (2018) Peripheral primitive neuroectodermal tumor of cauda equina: A report and review of literature. Neurol India 66(3): 850-852.

4. Gao L, Zhu Y, Shi X, Gao Z, Chen X (2019) Peripheral primitive neuroectodermal tumors: A retrospective analysis of 89 cases and literature review. Oncol Lett 18(6): 6885-6890.

5. Liu Y, Yuan Y, Zhang F, Hu K, Qiu J, et al. (2020) Outcome of multidisciplinary treatment of peripheral primitive neuroectodermal tumor. Sci Rep 10(1): 15656.

6. Garibaldi C, Jereczek-Fossa BA, Marvaso G, Dicuonzo S, Rojas DP, et al. (2017) Recent advances in radiation oncology. Ecancermedicalscience 11: 785 .

7. Sager O, Dincoglan F, Demiral S, Uysal B, Gamsiz H, et al. (2021) Omission of Radiation Therapy (RT) for Metaplastic Breast Cancer (MBC): A Review Article. International Journal of Research Studies in Medical and Health Sciences 6(1): 10-15.

8. Sager O, Dincoglan F, Demiral S, Uysal B, Gamsiz H, et al. (2020) Adaptive radiation therapy of breast cancer by repeated imaging during irradiation. World J Radiol 12(5): 68-75.
9. Sager O, Dincoglan F, Demiral S, Uysal B, Gamsiz H, et al. (2019) Utility of Molecular Imaging with 2-Deoxy-2-[Fluorine-18] Fluoro-DGlucose Positron Emission Tomography (18F-FDG PET) for Small Cell Lung Cancer (SCLC): A Radiation Oncology Perspective. Curr Radiopharm 12(1): 4-10.

10. Sager O, Dincoglan F, Demiral S, Uysal B, Gamsiz H, et al. (2019) Breathing adapted radiation therapy for leukemia relapse in the breast: A case report. World J Clin Oncol 10: 369-374.

11. Sager O, Dincoglan F, Uysal B, Demiral S, Gamsiz H, et al. (2018) Evaluation of adaptive radiotherapy (ART) by use of replanning the tumor bed boost with repeated computed tomography (CT) simulation after whole breast irradiation (WBI) for breast cancer patients having clinically evident seroma. Jpn J Radiol 36(6): 401-406.

12. Sager O, Dincoglan F, Uysal B, Demiral S, Gamsiz H, et al. (2017) Splenic Irradiation: A Concise Review of the Literature. J App Hem Bl Tran 1: 101.

13. Sager O, Beyzadeoglu M, Dincoglan F, Demiral S, Uysal B, et al. (2015) Adaptive splenic radiotherapy for symptomatic splenomegaly management in myeloproliferative disorders. Tumori 101(1): 84-90.

14. Ozsavaş EE, Telatar Z, Dirican B, Sager O, Beyzadeoğlu M (2014) Automatic segmentation of anatomical structures from CT scans of thorax for RTP. Comput Math Methods Med 2014: 472890.

15. Dincoglan F, Beyzadeoglu M, Sager O, Oysul K, Kahya YE, et al. (2013) Dosimetric evaluation of critical organs at risk in mastectomized leftsided breast cancer radiotherapy using breath-hold technique. Tumori 99(1): 76-82.

16. Sager O, Beyzadeoglu M, Dincoglan F, Oysul K, Kahya YE, et al. (2012) Evaluation of active breathing control-moderate deep inspiration breath-hold in definitive non-small cell lung cancer radiotherapy. Neoplasma 59(3): 333-340.

17. Sağer Ö, Dinçoğlan F, Gamsiz H, Demiral S, Uysal B, et al. (2012) Evaluation of the impact of integrated [18f]-fluoro-2-deoxy-D-glucose positron emission tomography/computed tomography imaging on staging and radiotherapy treatment volume definition of nonsmall cell lung cancer. Gulhane Med J 54: 220-227.

18. Sager O, Beyzadeoglu M, Dincoglan F, Oysul K, Kahya YE, et al. (2012) The Role of Active Breathing Control-Moderate Deep Inspiration BreathHold (ABC-mDIBH) Usage in non-Mastectomized Left-sided Breast Cancer Radiotherapy: A Dosimetric Evaluation UHOD - Uluslararasi Hematoloji-Onkoloji Dergisi 22(3): 147-155.

19. Sager O, Beyzadeoglu M, Dincoglan F, Demiral S, Gamsiz H, et al. (2020) Multimodality management of cavernous sinus meningiomas with less extensive surgery followed by subsequent irradiation: Implications for an improved toxicity profile. J Surg Surgical Res 6: 56-61.

20. Beyzadeoglu M, Sager O, Dincoglan F, Demiral S, Uysal B, et al. (2020) Single Fraction Stereotactic Radiosurgery (SRS) versus Fractionated Stereotactic Radiotherapy (FSRT) for Vestibular Schwannoma (VS). J Surg Surgical Res 6(1): 62-66.

21. Dincoglan F, Beyzadeoglu M, Sager O, Demiral S, Uysal B, et al. (2020) A Concise Review of Irradiation for Temporal Bone Chemodectomas (TBC). Arch Otolaryngol Rhinol 6(2): 16-20.

22. Dincoglan F, Sager O, Uysal B, Demiral S, Gamsiz H, et al. (2019) Evaluation of hypofractionated stereotactic radiotherapy (HFSRT) to the resection cavity after surgical resection of brain metastases: A single center experience. Indian J Cancer 56: 202-206.

23. Dincoglan F, Sager O, Demiral S, Gamsiz H, Uysal B, et al. (2019) Fractionated stereotactic radiosurgery for locally recurrent brain metastases after failed stereotactic radiosurgery. Indian J Cancer 56(2): 151-156.

24. Demiral S, Dincoglan F, Sager O, Uysal B, Gamsiz H, et al. (2018) Contemporary Management of Meningiomas with Radiosurgery. Int J Radiol Imaging Technol 4(2). 
25. Dincoglan F, Sager O, Demiral S, Uysal B, Gamsiz H, et al. (2017) Radiosurgery for recurrent glioblastoma: A review article. Neurol Disord Therap 1: 1-5.

26. Demiral S, Dincoglan F, Sager O, Gamsiz H, Uysal B, et al. (2016) Hypofractionated stereotactic radiotherapy (HFSRT) for who grade anterior clinoid meningiomas (ACM). Jpn J Radiol 34(11): 730-737.

27. Gamsiz H, Beyzadeoglu M, Sager O, Demiral S, Dincoglan F, et al. (2015) Evaluation of stereotactic body radiation therapy in the management of adrenal metastases from non-small cell lung cancer. Tumori 101(1): 98103.

28. Sager O, Dincoglan F, Beyzadeoglu M (2015) Stereotactic radiosurgery of glomus jugulare tumors: Current concepts, recent advances and future perspectives. CNS Oncol 4(2): 105-114.

29. Dincoglan F, Beyzadeoglu M, Sager O, Demiral S, Gamsiz H, et al. (2015) Management of patients with recurrent glioblastoma using hypofractionated stereotactic radiotherapy. Tumori 101(2): 179-184.

30. Demiral S, Beyzadeoglu M, Sager O, Dincoglan F, Gamsiz H, et al. (2014) Evaluation of Linear Accelerator (Linac)-Based Stereotactic Radiosurgery (Srs) for the Treatment of Craniopharyngiomas. UHODUluslararasi Hematoloji Onkoloji Dergisi 24(2): 123-129.

31. Gamsiz H, Beyzadeoglu M, Sager O, Dincoglan F, Demiral S, et al. (2014) Management of pulmonary oligometastases by stereotactic body radiotherapy. Tumori 100(2): 179-183.

32. Demiral S, Beyzadeoglu M, Sager O, Dincoglan F, Gamsiz H, et al. (2014) Evaluation of linear accelerator (linac)-based stereotactic radiosurgery (srs) for the treatment of craniopharyngiomas. UHOD - Uluslararasi Hematoloji-Onkoloji Dergisi 24(2): 123-129.

33. Dincoglan F, Sager O, Gamsiz H, Uysal B, Demiral S, et al. (2014) Management of patients with $\geq 4$ brain metastases using stereotactic radiosurgery boost after whole brain irradiation. Tumori 100(3): 302306.

34. Sager O, Beyzadeoglu M, Dincoglan F, Gamsiz H, Demiral S, et al. (2014) Evaluation of linear accelerator-based stereotactic radiosurgery in the management of glomus jugulare tumors. Tumori 100(2): 184-188.

35. Sager O, Beyzadeoglu M, Dincoglan F, Uysal B, Gamsiz H, et al. (2014) Evaluation of linear accelerator (LINAC)-based stereotactic radiosurgery (SRS) for cerebral cavernous malformations: A 15-year single-center experience. Ann Saudi Med 34(1): 54-58.

36. Sager O, Beyzadeoglu M, Dincoglan F, Demiral S, Uysal B, et al. (2013) Management of vestibular schwannomas with linear accelerator-based stereotactic radiosurgery: a single center experience. Tumori 99(5): 617-622.

37. Dincoglan F, Beyzadeoglu M, Sager O, Uysal B, Demiral S, et al. (2013) Evaluation of linear accelerator-based stereotactic radiosurgery in the management of meningiomas: A single center experience. J BUON 18(3): 717-722.

38. Demiral S, Beyzadeoglu M, Uysal B, Oysul K, Kahya YE, et al. (2013) Evaluation of stereotactic body radiotherapy (SBRT) boost in the management of endometrial cancer. Neoplasma 60(3): 322-327.

39. Dincoglan F, Sager O, Gamsiz H, Uysal B, Demiral S, et al. (2012) Stereotactic radiosurgery for intracranial tumors: A single center experience. Gulhane Med J 54(3): 190-198.

40. Dincoglan F, Beyzadeoglu M, Sager 0, Oysul K, Sirin S, et al. (2012) Image-guided positioning in intracranial non-invasive stereotactic radiosurgery for the treatment of brain metastasis. Tumori 98(5): 630635.

41. Sirin S, Oysul K, Surenkok S, Sager O, Dincoglan F, et al. (2011) Linear accelerator-based stereotactic radiosurgery in recurrent glioblastoma: A single center experience. Vojnosanit Pregl 68(11): 961-966.
42. Wang D, Bosch W, Roberge D, Finkelstein SE, Petersen I, et al. (2011) RTOG sarcoma radiation oncologists reach consensus on gross tumor volume and clinical target volume on computed tomographic images for preoperative radiotherapy of primary soft tissue sarcoma of extremity in Radiation Therapy Oncology Group studies. Int J Radiat Oncol Biol Phys 81(4): e525-e528.

43. Demiral S, Sager 0, Dincoglan F, Uysal B, Gamsiz H, et al. (2018) Evaluation of Target Volume Determination for Single Session Stereotactic Radiosurgery (SRS) of Brain Metastases. Canc Therapy \& Oncol Int J 12(5): 555848.

44. Sager O, Dincoglan F, Demiral S, Beyzadeoglu M (2019) Evaluation of Radiosurgery Target Volume Determination for Meningiomas Based on Computed Tomography (CT) And Magnetic Resonance Imaging (MRI). Cancer Sci Res Open Access 5(2): 1-4.

45. Dincoglan F, Sager O, Demiral S, Beyzadeoglu M (2019) Multimodality Imaging for Radiosurgical Management of Arteriovenous Malformations. Asian Journal of Pharmacy, Nursing and Medical Sciences 7(1): 7-12.

46. Sager O, Dincoglan F, Demiral S, Gamsiz H, Uysal B, et al. (2019) Utility of Magnetic Resonance Imaging (Imaging) in Target Volume Definition for Radiosurgery of Acoustic Neuromas. Int J Cancer Clin Res 6(3): 119.

47. Beyzadeoglu M, Sager O, Dincoglan F, Demiral S (2019) Evaluation of Target Definition for Stereotactic Reirradiation of Recurrent Glioblastoma. Arch Can Res 7(3).

48. Sager O, Dincoglan F, Demiral S, Gamsiz H, Uysal B, et al. (2019) Evaluation of the Impact of Magnetic Resonance Imaging (MRI) on Gross Tumor Volume (GTV) Definition for Radiation Treatment Planning (RTP) of Inoperable High Grade Gliomas (HGGs). Concepts in Magnetic Resonance Part A 2019.

49. Demiral S, Sager O, Dincoglan F, Beyzadeoglu M (2019) Assessment of Computed Tomography (CT) And Magnetic Resonance Imaging (MRI) Based Radiosurgery Treatment Planning for Pituitary Adenomas. Canc Therapy \& Oncol Int J 13(2).

50. Dincoglan F, Sager O, Demiral S, Beyzadeoglu M (2019) Incorporation of Multimodality Imaging in Radiosurgery Planning for Craniopharyngiomas: An Original Article. SAJ Cancer Sci 6: 103.

51. Sager O, Dincoglan F, Demiral S, Beyzadeoglu M (2020) Evaluation of Target Volume Determination for Irradiation of Pilocytic Astrocytomas: An Original Article. ARC Journal of Cancer Science 6(1): 1-5.

52. Demiral S, Sager 0, Dincoglan F, Beyzadeoglu M (2019) Assessment of target definition based on Multimodality imaging for radiosurgical Management of glomus jugulare tumors (GJTs). Canc Therapy \& Oncol Int J 15(2): 555909.

53. Demiral S, Beyzadeoglu M, Dincoglan F, Sager O (2020) Evaluation of Radiosurgery Target Volume Definition for Tectal Gliomas with Incorporation of Magnetic Resonance Imaging (MRI): An Original Article. Biomedical Journal of Scientific \& Technical Research (BJSTR) 27: 20543-20547.

54. Beyzadeoglu M, Dincoglan F, Demiral S, Sager O (2020) Target Volume Determination for Precise Radiation Therapy (RT) of Central Neurocytoma: An Original Article. International Journal of Research Studies in Medical and Health Sciences 5(3): 29-34.

55. Demiral S, Beyzadeoglu M, Dincoglan F, Sager O (2020) Assessment of Target Volume Definition for Radiosurgery of Atypical Meningiomas with Multimodality Imaging. Journal of Hematology and Oncology Research 3: 14-21.

56. Sager O, Dincoglan F, Demiral S, Beyzadeoglu M (2020) Radiosurgery Treatment Volume Determination for Brain Lymphomas with and without Incorporation of Multimodality Imaging. Journal of Medical Pharmaceutical and Allied Sciences 9(1): 2398-2404. 
57. Beyzadeoglu M, Dincoglan F, Sager O, Demiral S (2020) Determination of Radiosurgery Treatment Volume for Intracranial Germ Cell Tumors (GCTS). Asian Journal of Pharmacy, Nursing and Medical Sciences 8(3): 18-23.

58. Sager O, Demiral S, Dincoglan F, Beyzadeoglu M (2020) Target Volume Definition for Stereotactic Radiosurgery (SRS) Of Cerebral Cavernous Malformations (CCMs). Canc Therapy \& Oncol Int J 15(4): 555917.

59. Dincoglan F, Beyzadeoglu M, Demiral S, Sager O (2020) Assessment of Treatment Volume Definition for Irradiation of Spinal Ependymomas: an Original Article. ARC Journal of Cancer Science 6(1): 1-6.

60. Sager O, Dincoglan F, Demiral S, Beyzadeoglu M (2020) Evaluation of Treatment Volume Determination for Irradiation of chordoma: an Original Article. International Journal of Research Studies in Medical and Health Sciences 5(10): 3-8.

61. Dincoglan F, Demiral S, Sager 0, Beyzadeoglu M (2020) Utility of Multimodality Imaging Based Target Volume Definition for Radiosurgery of Trigeminal Neuralgia: An Original Article. Biomed J Sci \& Tech Res 26: 19728-19732.

62. Sager O, Dincoglan F, Demiral S, Beyzadeoglu M (2020) Assessment of Target Volume Definition for Irradiation of Hemangiopericytomas: An Original Article. Canc Therapy \& Oncol Int J 17(2).

63. Dincoglan F, Demiral S, Sager O, Beyzadeoglu M (2021) Evaluation of Target Definition for Management of Myxoid Liposarcoma (MLS) with Neoadjuvant Radiation Therapy (RT). Biomed J Sci \& Tech Res 33: 26171-26174.

ISSN: 2574-1241

DOI: 10.26717/BJSTR.2021.34.005586

Selcuk Demiral. Biomed J Sci \& Tech Res

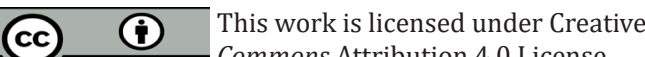

Submission Link: https://biomedres.us/submit-manuscript.php
64. Demiral S, Dincoglan F, Sager 0, Beyzadeoglu M (2021) Assessment of Multimodality Imaging for Target Definition of Intracranial Chondrosarcomas. Canc Therapy \& Oncol Int J 18(2).

65. Dincoglan F, Sager 0, Demiral S, Beyzadeoglu M (2021) Impact of Multimodality Imaging to Improve Radiation Therapy (RT) Target Volume Definition for Malignant Peripheral Nerve Sheath Tumor (MPNST). Biomed J Sci \& Tech Res 34: 26734-26738.

66. Sager O, Dincoglan F, Demiral S, Beyzadeoglu M (2021) Treatment Volume Determination for Irradiation of Recurrent Nasopharyngeal Carcinoma with Multimodality Imaging: An Original Article. ARC Journal of Cancer Science 6: 18-23.

67. Demiral S, Dincoglan F, Sager O, Beyzadeoglu M (2021) Multimodality Imaging Based Target Definition of Cervical Lymph Nodes in Precise Limited Field Radiation Therapy (Lfrt) for Nodular Lymphocyte Predominant Hodgkin Lymphoma (Nlphl). ARC Journal of Cancer Science 6: 06-11.

68. Dincoglan F, Sager O, Demiral S, Beyzadeoglu M (2021) Target Definition of orbital Embryonal Rhabdomyosarcoma (Rms) by Multimodality Imaging: An Original Article. ARC Journal of Cancer Science 6: 12-17.

$\begin{array}{ll}\text { BIOMEDICAL } & \text { Assets of Publishing with us } \\ \text { RESEARCHES } & \text { Global archiving of articles } \\ \text { - Immediate, unrestricted online access } & \text { - Rigorous Peer Review Process } \\ & \text { - Authors Retain Copyrights }\end{array}$

